\title{
Research on Changes of Foreign Language Literature under Knowledge Economy Era
}

\author{
Dongyang $\mathrm{Xu}^{1}$ \\ ${ }^{1}$ Zhengzhou University of Industrial Technology, Zhengzhou, Henan, China, 451100
}

\section{KEYWORDS: Knowledge Economy Era; Foreign Language Literature; Changes}

\begin{abstract}
With the advent of the knowledge economy era, as well as universal human social and cultural development of information technology, foreign language and literature development system are constantly changing them. To change foreign language and literature of the era of comprehensive economic study and discussion, not only summed up the trend of social development, but also help people to change society, self-sublimation.
\end{abstract}

\section{Introduction}

Foreign Language and Literature consists of two aspects, one is standing outside of our culture in other countries or regional cultures, and the second is our specially set up based on higher professional education under this foreign culture, namely Western Literature. Foreign Language and Literature Language and Literature, namely with respect to the country or territory other than our native language and literature belongs, is part of the human and social sciences. In the past period of time, the integration of the world economy led the integration of the development of world culture, at the same time, the geographical barriers between cultures gradually broken, gradually there has been convergence between culture and culture, the economy and culture binding trends become contemporary social trends and even in the future for a period of time in history. In order to adapt to the changes and development of the world community, in our education system which focuses on the foreign language and literature related professional set up, these professionals uphold the scientific concept of education, with the development of the times and constantly change. However, reform and change at the same time, and not blindly follow what direction to change some elements or principles.

\section{The Change in the Foreign Language Literature Environment at Knowledge Economy Era}

Any culture or civilization must be due to the development of social production and production, its development is also being driven changes in social production. For example: My feudal culture system is feudal land ownership, based around certain human cognition, social system, ideology and other special performance carried out. The famous "Renaissance", the same is by promoting the development of the capitalist economy. Therefore, in the era of knowledge economy, the world economy was growing integration trend, the economic behavior of the countries between regions continue to close up. In this trend, social language and literature is bound by the changing economic environment and produce some changes, perhaps adding some new elements, or is the manifestation of change. Therefore, economic development and may change as a foundation of foreign language and literature studies. 
On the one hand, with the development of network information technology, communication between people has been achieved beyond the limits of space, contact and remote links become a reality. In remote communication and exchange of technology as the carrier, people gradually developed a new kind of language and literature - Network Language and Literature. This kind of network technology as the basis of language and literature has gradually become the trend of the contemporary world. In the extensive exchange, propagation conditions, foreign language and literature continue to be affected by this new element of the Internet, and gradually developed into a network with cultural flavor. On the other hand, such as computer technology, voice input technology development and application, the people's language and literature form of the addition of a carrier, that is from the traditional written or verbal timely realization of recording or book form more conducive to innovation and dissemination.

In the world economy and the world of science and technology to promote development and safeguard cultural environment gradually expanded from original regional culture to the world stage. At the same time, other regions of the world culture are also through the appropriate channels, or the way the indigenous culture had an impact. In this long-term cultural "exchange", the traditional cultures of various regions have begun to produce a foreign culture tolerant attitude, and gradually formed a fusion trend. For example, in recent years, with the upgrading of China's comprehensive national strength, China foreign culture continue to be recognized and accepted by society, some foreign cultures has begun between Chinese culture and tried to fusion, and has made certain achievements. It has been evaluated, to say that "Kung Fu Panda 1" to show the Chinese culture can only be "mere copycat" as the failure to make and the "Kung Fu Panda 2" is the depth of interpretation of Chinese culture.

It can be said of political influence, it is the biggest factor in Foreign Language and Literature Development. In the era of knowledge economy, the linkages between the various regions of the world increased and there has been a series of regional integrated administrative organization in political terms. For example: the European Union, the United Nations. Under this political environment, it must be based on a small number of languages as the official language. This creates certain restrictions for the development of language and literature of the world, but also provides a strong impetus. For the official language is concerned, this political demand as they provide a direct external influence and opportunity to spread, and for other countries or regions in terms of language, such a system so that they can find a way to better display their characteristics.

\section{Development Principles of Foreign Language Literature at the Age of Knowledge Economy}

Western mainly related disciplines of knowledge and academic research, research that is both English language and literature, Russian language and literature and other two subjects, or linguistics, literature, culture, translation, language teaching, the knowledge system should be improved, more comprehensive reflect the subject content, the development of history, trends; its academic disciplines should reflect cutting-edge, forward-looking areas of concern, with leading academic nature.

Mainly related to foreign language subjects layout, personnel training, academic research, academic team building, etc., that respond to various Western disciplines meet national and regional demand, combined with characteristics of the host institutions, a clear disciplinary position, subject to optimize the layout to determine the target of talent, cultivate an international perspective , a unique cross-cultural talent; while in academic research and development of qualified personnel, the prominent international awareness, through international exchanges and cooperation in research and teaching, and enhance the overall quality, and expand international academic discourse. 
Each subject should establish a Western academic development philosophy, emphasizing innovation and institutional mechanisms to promote interdisciplinary cooperation, promotion of sustainable development. Interdisciplinary integration helps maintain the vigor and vitality of the discipline, only to close cooperation between the various Western disciplines two disciplines, brought together high-quality resources, but also to intensify integration with other disciplines between disciplines develop new growth points.

\section{Development Ideas of Foreign Language Literature at the Era of Knowledge Economy}

Docking national strategy, the overall planning of the overall planning of the development of Western disciplines

Western discipline that is sufficient to consider the issue disciplinary position, subject layout, concept development, personnel training, research promotion, development of teachers and other aspects. Macro level, the Ministry of Education, according to the national strategic needs, the introduction of Western disciplines philosophy and strategy, highlighting the cultural heritage of innovation, solve multidisciplinary teams, landmark achievement, academic discourse system, discipline go out and other issues of national foreign language subject development planning and guide. The micro level, the university foreign language subject should have specific plans. For a long time, more colleges and universities to develop units of Secondary Colleges faculty development plan, which covers the subject development planning, but planning department, after all, different disciplines and planning in the development of objectives, content construction, construction of key and so on. Necessary by the experts or foreign language and literature disciplines two disciplines each academic committee was planning to solicit opinions and in-depth analysis on the basis of clear disciplinary position, the implementation of dislocation competition and avoid disciplinary homogeneity, the lack of features.

The implementation of the concept of two-way international, pluralistic culture intellectuals across Dai Weidong said in "cultural going out" process, we still lack a large number of high-end research talent, outstanding classics translators, simultaneous interpretation of international conferences, staff of international organizations financial personnel and other Western law. Wang Ning suggested that "culture going out" from the national implementation of the strategic objectives, the acute shortage of high-level English language skills, excellent translators in demand everywhere, and can Chinese literature translated into foreign languages and published in the target language country are more It is rare.

Create an international teaching and research team, to promote the professional development of teachers on an international teaching and research in terms of team building, all colleges and universities Western disciplines may adhere to the "outer primer" and "inner culture" combined with the introduction of leading talent at home and abroad on the one hand the implementation of the project , the introduction of leading talent language, literature, translation, culture, education and the direction of Chinese language Council international, a world-class talent in particular, imposed permanent track mechanism to require them to guide the academic team, the introduction of international cooperative projects, published the results of an international, so as to fully academic play a leading role. On the other hand requires a high level of discipline butt research and teaching to senior professors led to teachers mainly to promote a high level of international cooperation in scientific research and teaching reform and innovation. Simultaneously lecturing overseas high-end projects, invite both academic courses and famous frontier offer a series of lectures, but also encouraged the subject specialist courses or seminars at overseas universities, and gradually bring up a number of international standards and the influence of the "culture of going out" talent. 
Effective use of big data, rich cultural resources and transmission routes with the development of the Internet, big data concept has gradually entered the education sector. Big data has a large capacity and variety, fast, high-value features, and change the thinking leads to three: the analysis of all data related to something, rather than the small amount of data; receptive complex data, rather than the pursuit of accuracy; correlation between concern things and not causation. These changes provide for teaching massive resources to optimize the learning environment, help to promote the development of personalized foreign language education, the dissemination of the rich cultural resources and means.

\section{Conclusion}

Era of knowledge economy is an era of technological, economic, and cultural development of the highly centralized, interaction between various social elements and combined, so that also developed into a unique language and literature in the new century, a grid of things. Such changes and development and innovation is not only in the form of theme, but also increase the connotation elements. In this social context, not only the foreign language and literature in changing, even our Chinese language and literature and relevant education system is continually adjust and reform them. Discovery and development of changes in foreign language and literature, as a contemporary intellectuals have long-term development of the eyes and performance. Only in an integrated environment for all kinds of foreign language and literature and in-depth comparison of Chinese language and literature, science will be able to find out the direction of development of human language and literature, and then find for our unique development and reform of the social system of science and education system direction and reference. Meanwhile, the era of knowledge economy emphasizes science and technology, systems, human resources and other elements, therefore, in the social sciences summarized research also should play an active role in people's efforts to optimize the social environment, the use of all available resources, will only belong to humans language and Literature step by step into the future of society.

\section{Reference:}

[1] Dai Weidong, Wang Xuemei. Reflections on the Foreign Language and Literature strategic planning [J]. Foreign Language World, 2012, (3): 2-9.

[2] Dai Weidong. The professional education targeting foreign language layout and development [J]. Modern Foreign Languages, 2010, (10): 84-85.

[3] Fang Wen. The evolution of social psychology: A Perspective of Discipline System [J]. Chinese Social Science, 2010, (10): 24-28.

[4] Geng Qiang. The intercultural communication "Panda Series" English translation [J]. PLA University of Foreign Languages, 2008, (10): 72-75.

[5] Huang Zhonglian. The cultural output needs a strong proponent of "Flexible Translation" [J]. Guangming Daily, 2010, (10): 101-103.

[6] Jiang Xiaoping. The France interdisciplinary research and Model [J]. Foreign Social Sciences, 2010, (10): 25-28. 